\title{
Haemolytic Disease of Newborn due to Minor Blood Group C Incompatibility- A Case Report
}

\author{
Kelawala Pooja M. ${ }^{1}$, Mangal Dhananjay², Singh Sourabh ${ }^{3}$, Singhal Chanchal ${ }^{4}$ \\ ${ }^{1}$ NNF Fellowship, Department of Paediatrics, Babylon Hospital, Jaipur, Rajasthan, India. \\ ${ }^{2}$ Consultant, Department of Paediatrics and Neonatology, Babylon Hospital, Jaipur, Rajasthan, India. \\ ${ }^{3}$ Consultant, Department of Neonatology and Paediatrics, Babylon Hospital, Jaipur, Rajasthan, India. \\ ${ }^{4}$ Consultant, Department of Paediatrics, Babylon Hospital, Jaipur, Rajasthan, India.
}

\section{INTRODUCTION}

Haemolytic disease of newborn is defined as incompatibility between foetal/neonatal and mother's blood resulting in foetal/neonatal RBC destruction causing hyperbilirubinaemia in the neonatal period. The most common causes include $\mathrm{Rh}$ and ABO incompatibility which can cause clinically significant Hyperbilirubinemia. Apart from the above causes, subgroup incompatibilities also account for 3-5\% of all newborn jaundice.(1) The most common subgroup incompatibilities are; non-D Rh antigens (c, C, E, e), Kell, Duffy, Kidd and MNS. Subgroup incompatibilities may range from subclinical haemolysis to severe haemolysis requiring exchange transfusion. Incidence of Haemolytic disease of newborn due to subgroup mismatch has been increasing significantly. In this article, we are discussing a 2-day old newborn with ' $c$ ' subgroup incompatibility, presented with signs of severe haemolysis such as anaemia, hyperbilirubinaemia and positive direct coomb's test, controlled with double volume exchange transfusion, intensive phototherapy and intravenous immunoglobulin.

\section{PRESENTATION OF CASE}

A 39 weeks male neonate, $3.14 \mathrm{~kg}$, born to a 23-year-old 2nd gravida mother through normal vaginal delivery, cried immediately at birth, was referred to our NICU at $36^{\text {th }}$ hour of life with complaint of yellowish discolouration of skin, noted from $2^{\text {nd }}$ hour of life by parents. On NICU admission, patient's general condition was fair with normal vitals. Child was deeply icteric observed till soles; pallor was present. Child was active, alert with good spontaneous activity and normal cry, anterior fontanelle at level and normal neonatal reflexes, had hepato-splenomegaly, respiratory and cardiovascular findings were normal. There were no risk factors for sepsis, no maternal morbidity and no congenital anomaly. Serum bilirubin at $36^{\text {th }}$ hour of life was $20.2 \mathrm{mg} / \mathrm{dl}$ with indirect bilirubin of $19.1 \mathrm{mg} / \mathrm{dl}, \mathrm{Hb}: 11 / 1$. Laboratory investigations demonstrated mother's and baby's blood group to be 0 positive, reticulocyte count was $4.6 \%$, G6PD normal and positive DCT. Thus, decision was made, and double volume exchange transfusion was done under strict sterile and aseptic condition and intensive phototherapy was given. No apparent cause for immune haemolytic disease such as Rh and ABO incompatibility was present and DCT was positive, so further investigation for minor blood group incompatibility was done which revealed that anti-c antibody was present in mother and ' $c$ ' antigen in patient. This established our diagnosis of anti-c haemolytic disease due to minor blood group c incompatibility as a cause of hyper bilirubinaemia in neonate. Since DCT was positive, IVIG was given to patient. A final diagnosis of neonatal hyper bilirubinaemia in term, appropriate for gestational age, male neonate due to anti-c alloimmunisation was made. Child's jaundice with reticulocyte count reduced gradually and was discharged at $7^{\text {th }}$ day of life with regular follow-up in high risk clinic. BERA was planned at 12 th week of life. Till date, infant has normal growth and development.
Corresponding Author: Dr. Pooja Kelawala, \#311, Sewa Sadan Marg, Adarsh Nagar, Raja Park, Jaipur-302004, Rajasthan, India. E-mail: poojakelawala@yahoo.co.in

DOI: $10.14260 / j e m d s / 2019 / 613$

Financial or Other Competing Interests: None.

How to Cite This Article:

Pooja KM, Dhananjay M, Sourabh S, et al. Haemolytic disease of newborn due to minor blood group c incompatibility- a case report. J. Evolution Med. Dent. Sci. 2019;8(36):2826-2827, $10.14260 /$ jemds $/ 2019 / 613$

Submission 01-07-2019, Peer Review 23-08-2019, Acceptance 30-08-2019, Published 09-09-2019. 


\section{DISCUSSION OF MANAGEMENT}

The etiopathogenesis for any haemolytic disease due to blood group incompatibility is based on the formation of antibodies in the mother against antigens in the RBCs of the newborn. The most common cause of pathological jaundice in neonate is $\mathrm{Rh}$ and $\mathrm{ABO}$ incompatibility. This syndrome appears to affect only 0.3 to $2.2 \%$ of infants out of $15 \%$ live births who presented with above risk.(2)

In HDN, also known as Erythroblastosis foetalis, foetal RBCS possessing an antigen that mother usually lacks, cross the placenta into maternal circulation. This leads to stimulation of antibody production in maternal blood, which returns to foetal circulation and destroys foetal RBCS. It may occur due to various factors including blood group incompatibilities. Out of which, Rh (D antigen) accounts for almost $50 \%$ of maternal alloimmunisation.(3) Widespread use of anti-D gamma globulin has eventually decreased the rate of haemolytic anaemia and hyper bilirubinaemia due to $\mathrm{Rh}$ incompatibility and thus, the importance of minor blood group incompatibility has increased.(4)

The most common minor blood group antigens causing blood incompatibility between baby and mother are C, c, E. e, Kell, Duffy, Diego, Kidd and MNSs antigen systems.(5) In haemolytic disease due to minor blood group incompatibility, the disease spectrum can range from subclinical haemolysis to active haemolysis and hyper bilirubinaemia requiring exchange transfusion. Its diagnosis and management is similar to $\mathrm{Rh}$ incompatibility.(2) In our case, child was diagnosed with anti-c haemolytic disease and hyper bilirubinaemia and treated with double volume exchange transfusion, phototherapy and responded well. One study GeifmanHoltzman et al, determining the frequency of antibodies which led to development of haemolytic disease causing mortality among 452 neonates with positive Indirect Coombs test shows anti-D: $18.4 \%$, anti-E: $14 \%$, anti-c: $5.8 \%$, anti-C: $4.7 \%$, antiKell: $22 \%$, anti-MNS: $4.7 \%$, anti-Fya (Duffy)- 5.4\%, and anti-

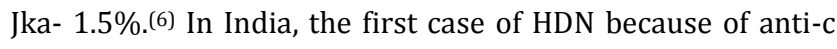
antibodies in Rh-D positive mother was published in a retrospective diagnosis made in 2007.(7)

Direct coombs test was found to be positive in $33 \%$ of the cases in the studies carried out for subgroup incompatibility. However, DCT may not always be positive or negative due to poor antigenic properties of subgroup antigens. ${ }^{(8)}$ In our patient, DCT was positive which suggested severe haemolysis. In Turkish Neonatology Association Jaundice Guide, it was stated that IVIG can be used in the presence of bilirubin levels close to the blood exchange limits in the neonates with haemolytic disease due to blood group incompatibilities including $\mathrm{Rh}, \mathrm{ABO}$ and minor blood groups.(9) American Academy of Pediatrics also states the same to give IVIG in patients with hyperbilirubinaemia close to blood exchange limits at a dose of 0.5 to $1.0 \mathrm{gm} / \mathrm{kg}$, to be repeated 12 hourly if required. However In a meta-analysis conducted in 2014 of $463 \mathrm{Rh}$ and $350 \mathrm{ABO}$ incompatibility cases, use of IVIG did not reduce chances of exchange transfusion.(10) Although there are conflicting publications on the use of IVIG, we have administered at a dose of $1 \mathrm{gm} / \mathrm{kg}$ to our case due to anaemia, hyper bilirubinaemia and high reticulocytes count suggesting severe haemolysis and clinical benefit was obtained in halting haemolysis.

\section{CONCLUSIONS}

In conclusion, paediatricians should always consider minor blood group compatibility in cases of severe haemolysis with hyperbilirubinemia and positive DCT even if major blood group incompatibility is not detected. Also, obstetricians should include screening for alloantibodies to minor RBC antigens in mothers. If antibodies are detected, then foetus should be closely monitored for any signs of haemolysis and also postnatally, anaemia and hyper bilirubinaemia should be kept in mind.

\section{REFERENCES}

[1] Dey SK, Afroze S, Jahan I, et al. Neonatal hyperbilirubinemia associated with minor blood group incompatibility: two case reports. Bangladesh J Child Health 2017;41(1):64-6.

[2] Rath ME, Smits-Wintjens VE, Walther FJ, et al. Hematological morbidity and management in neonates with haemolytic disease due to red cell alloimmunization. Early Human Dev 2011;87(9):583-8.

[3] Dean L. The Rh blood group. In: Blood groups and red cell antigens. Betheda: National Library of Medicine (US), NCBI, 2006.

[4] Sarici SU, Alpay F, Yesilkaya E, et al. Haemolytic disease of the newborn due to isoimmunisation with anti-E antibodies: a case report. Turk J Pediatr 2002;44(3):24850.

[5] Ozkan M, Sevinc S, Erkan VB, et al. Hyperbilirubinemia due to minor blood group (anti-E) incompatibility in a newborn: a case report. Turk Pediatr Ars 2017;52(3):162-4.

[6] Geifman-Holtzman O, Wojtowycz M, Kosmas E, et al. Female alloimmunisation with antibodies known to cause haemolytic disease. Obstet Gynecol 1997;89(2):272-5.

[7] American Academy of Pediatrics Subcommittee on Hyperbilirubinemia. Management of hyperbilirubinemia in the newborn infant 35 or more weeks of gestation. Pediatrics 2004;114(1):297-316.

[8] Ozkaya H, Bahar A, Ozkan A, et al. Neonatal period anemia with symptoms that minor blood group (anti-c, anti-E) nonconformity connected Haemolytic disease. Turk Pediatri Ars 2000;35:30-5.

[9] Çoban A, Türkmen MK, Gürsoy T. Turkish Neonatal Society guideline to the approach, follow-up and treatment of neonatal Jaundice. Turk Pediatri Ars 2018;53(Suppl 1):S172-9.

[10] Louis D, More K, Oberoi S, et al. Intravenous IVIG in isoimmune haemolytic disease of newborn: an updated systemic review and meta-analysis. Arch Dis Child Foetal Neonatal Ed 2014;99(4):F325-31. 